\title{
Chemical Composition and Biological Activities of Beebread - Review
}

\author{
Adriana URCAN ${ }^{1}$, Liviu Al. MĂRGHITAȘ ${ }^{1}$, Daniel S. DEZMIREAN ${ }^{1}$, Otilia BOBIȘ ${ }^{1}$, Victorița BONTA ${ }^{1}$, \\ Carmen I. MUREȘAN ${ }^{1}$, Rodica MĂRGĂOAN ${ }^{2 *}$ \\ ${ }^{1}$ Departament of Beekiping and Sericiculture, University of Agricultural Sciences and Veterinary \\ Medicine Cluj- Napoca, Romania \\ ${ }^{2}$ Departament of Micropropagation, University of Agricultural Sciences and Veterinary Medicine Cluj- \\ Napoca, Romania \\ ${ }^{*}$ corresponding author: rodica.margaoan@usamvcluj.ro
}

Bulletin UASVM Animal Science and Biotechnologies 74(1)/ 2017

Print ISSN 1843-5262; Electronic ISSN 1843-536X

DOI:10.15835/buasvmcn-asb: 12646

\begin{abstract}
Beebread is a product of the hive obtained from pollen collected by bees, to which they add honey,digestive enzymes and subsequently is stored in the combs. The bees transform the bee pollen in beebread by an anaerobic fermentation process.A proper hive management promotes beebread collection, aimed at marketing it for human consumption since it can be considered a valuable food supplement due to its content of a wide range of nutrients. Its value is given by the content in protein, amino acids, fatty acids, carbohydrates, mineral salts, polyphenols and flavonoids, which depends on the botanical source of bee pollen. The nutritional and functional composition of beebread is widely reported; nevertheless, few studies on transformation processes of the pollen to improve the availability of the compounds present in this product were found. Overall, beebread is a recent collected and consumed bee product and at this stage it can be used as a food supplement.
\end{abstract}

Keywords: beebread, biologic compounds, chemical composition

\section{Introduction}

Beekeepers, until some years ago, do not collect beebread since the inherent difficulty of extraction that force the beekeeper to partially destroy the hive (Fuenmayor, 2009), and preferably they collected pollen through well-designed systems of traps and containers (Almeida-Muradianet al., 2005), this bee product being more intended to human consumption. However, several reports have shown how beebread has and increased availability of nutrients and bioactive components with respect to pollen (Fuenmayor, 2009; Del Risco et al., 2012). Currently, specialized materials and devices have been designed to extract beebread without any damage to the hive (Zuluaga et al., 2015).

A proper hive management promotes beebread collection, which aims at marketing it for human consumption. Beebread can be considered a food supplement due to its content of a high range of nutrients. One of the contributions to their high nutritional value is the presence of significant amounts of proteins, carbohydrates, lipids, vitamins and phenolic compounds as natural antioxidants. The potential application of beebread as a food and as a nutraceutical supplement depends in a greater extent on its chemical composition which varies directly with the flora of the region and the time of collection by the bees (Markiewicz-Żukowska et al., 2013).

Therefore beebread has become lately a product of high commercial value and a fair evaluation of chemical composition is needed to guarantee the quality. Nowadays, there are different proposals for standardization in several countries, but Russia 
is the only one who already has a standard for this product (GOST R 53408-2009,2009/1/1).

Beebread is in fact fermented and naturally preserved pollen. Pollen is gathered by bees and mixed with its own digestive enzymes, carried in the hive and preserved with a tiny layer of honey and bee wax. Some studies indicate that it is necessary the fermentation process to modify the outer layer overlying the pollen known as exine, made of sporopollenin, a compound that provides chemical resistance to pollen and preserves the compounds which are within it, and responsible for the limited capacity for absorbing nutrients and bioactive substances that are inside the pollen grain (Atkin et al., 2011 cited by Zuluaga et al., 2015). The bees are able to transform the bee pollen in beebread by an anaerobic fermentation process. Pollen transformation in beebread occurs as a result of successive interventions of different enzymes, some species of microorganisms such as Pseudomonas, Lactobacillus, Saccharomyces that are naturally present in pollen, moisture and temperature (35- 36 $\mathrm{C}$ ) (Barene at al., 2015).During this fermentation, the wall of the pollen is disrupted and in this way the beebread has a better bioavailability.Comparatively with bee pollen, beebread is better tolerated by the human organism and has a lower $\mathrm{pH}$ (3.8-4.3) duo to its content of lactic acid which offers a good stability during the storage at room temperature (Berene et al., 2015).

Aime: This bibliographic study aims to present a brief review of the most important scientific findings and research regarding beebread chemical composition and its biological activities such as antioxidant and antimicrobial action.

Beebread chemical compositiondepends on plants from where worker bees have collected pollen and can vary widely; even in the same apiary or bee hive, no identical samples of beebread may be found (Isidorov et al., 2009). Beebread has a nutritional and compositional value that differs from bee pollen and has new nutrients, such as vitamin K (Nagari, 2004).

For honey bee colonies, the nutrients needed to grow colony populations and maintain their health come from nectar and pollen. Nectar provides carbohydrates and pollen supplies the remaining dietary requirements such as protein, lipids, vitamins, and minerals (Brodschneider and Crailsheim,2010).Nevertheless, bees do not consume either nectar or pollen directly; in both cases they induce biochemical changes, so nectar is transformed into honey and pollen into beebread (Krell, 1996).

Beebread is primarily composed of water, proteins, free amino acids, some bioactive compounds, fatty acids, and carbohydrates (Del Risco, 2012).

\section{Proteins and amino acids}

Beebread protein content is one of its most regarded nutritional features; According to the literature data this value ranged from 14.1 to 37.3 $\mathrm{g} / 100 \mathrm{~g}$ (dry basis) evaluated by using factor $\mathrm{N}$ x 6.25, having a $23.1( \pm 2.9) \mathrm{g} / 100 \mathrm{~g}$ mean. It is expected that the content of protein in beebread be similar to bee pollen (about $23.8 \mathrm{~g} / 100 \mathrm{~g}$ ) (Fuenmayor et al., 2014), since the biochemical process induced by bees is aimed in degrading the outer layer of the pollen grain, without any damage of inner content (Zuluaga et al., 2015).

The enzymes found in beebread include amylase, phosphatase and glucose-oxidase (SalazarGonzález et al., 2016).

Beebread contains also amino acids as glutamic acid, aspartic acid, proline, found in the largest quantity, arginine, valine, histidine, leucine, isoleucine, lysine, methionine, tryptophan, phenylalanine, threonine, cysteine, tyrosine, alanine, glycine and serine (Berene et al., 2015).

The presence of proline and glutamic acid is associated with bee pollen quality; glutamic acid concentration greater than $20 \mathrm{mg} / \mathrm{g}$ indicates freshness, whereas lower proline value indicatesaging and technological process (DominguezValhondo et al., 2011).

\section{Lipids}

According to the literature, the lipids content of raw beebread varies widely depending on the plant origin of pollen that is produced. Lipids are represented by fatty acid which contribute to the biological value of this bee product.

There are only few papers published on the fatty acids composition of the beebread. Human and Nicolson (2006) reported only 18 fatty acids in beebread from an indigenous South African bee. Čeksterytèet al., (2008) identified twenty-two fatty acids in beebread (containing $>45 \%$ rape or willow pollen) collected in the spring and summer 
seasons, including five $\omega-3$, four $\omega-6$ and three $\omega-9$ polyunsaturated fatty acids. Octadecenoic and icosa-tetraenoic acids were the most abundant unsaturated fatty acids, constituting around $15 \%$ of total fatty acids.

In another study, Čeksterytė and Jansen in 2012 reported the highest content (27-43.8\%) of octadecatrienoic acid ( $\omega-3)$ among 22 fatty acids identified in spring rape and willow beebread. Fatty acids are compounds of high importance in fertility and health of the honeybees.

Current literature suggests that beebread is a good source of polyunsaturated fatty acids (PUFAs) that are crucial for human nutrition. PUFAs cannot be synthesized in human body endogenously and must be obtained from food.

The ratio between unsaturated/saturated fatty acids in beebread and bee pollen is closely associated with the same indices obtained in raw and processed yolk where it reached values of 0.58 and 0.64 , respectively. Comparison of PUFA composition of yolk with that of beebread and bee pollen evidenced that all these products possessed the same fatty acids (Čeksterytė et al., 2016).

In this respect, beebread can be considered as a potential source of PUFAs in human diet. However, in particular, scientific research exploring various properties of beebread is scarce and additional research into this topic is highly required (Muammer et al., 2016).

\section{Carbohydrates}

The beebread carbohydrate content varies very widely depending on the origin of the pollen. According to chemical analysis we can say that an average content of beebread in carbohydrates is between $24.40-34.80 \%$ (Berene et al.,2015). Fructose is found in the largest amount $(57,51 \%$ of the total fresh weight), followed by glucose $(42,59 \%$ of the total fresh weight) and maltose $(3,37 \%$ of the total fresh weight) (Stanciu et al.,2008).

Sucrose accounted for $0.12 \%$ which reflect its hydrolysis decomposition in the monosaccharide's during lactic fermentation of the pollen and its transformation in beebread.The remaining disaccharides (trehalose, turanoe and isomaltose) represent about $1,82 \%$ of the total fresh weight.In the natural process of fermentation which occurs in the hive, Lactobacillus sp., uses carbohydrates as a source of oxygen and produce lactic acid up to a concentration of $3.2 \%$, a fact which inactivates the Lactobacillus sp.(Stanciu et al.,2008).

\section{Minerals}

Considering chemical composition, besides the compounds mentioned, beebread also includes: minerals such as $\mathrm{Ca}, \mathrm{Mg}, \mathrm{P}, \mathrm{Fe}, \mathrm{Na}, \mathrm{K}, \mathrm{Al}$, Mn, S, Cu (Anđelković et al., 2012). In beebread, potassium content occurred in the highest concentration $(0.74 \%)$ followed by calcium and phosphorus (0.65\%). The content in iron (121.99 $\mathrm{mg} / \mathrm{kg}$ ) and zinc $(44.09 \mathrm{mg} / \mathrm{kg}$ ) is also high in beebread (Stanciu et al., 2009).

In the study made by Anđelković, et al., (2012) who compared bee pollen with beebread the results show that the ash content of beebread is increased with $7.54 \%$ compared to bee pollen. Also the content of calcium, potassium, phosphorus, magnesium and iron increased compared to pollen. However, zinc and manganese content decreased. This decrease can be explained by microbial activity and chemical reactions that occur in the transformation of pollen in beebread (Foote, 1957; Haydak, 1958).

However, other factors such as geographical conditions and soil also affect the mineral content of beebread.

\section{Beebread biological activities and effects}

There are many studies that aim to evaluate the antioxidant activity of beebread samples of different geographical origin and establishing a correlation with the content of phenols, botanical origin and other compounds. The results in most of the research show large variations and significant differences in the amount and content of phenolic compounds found in beebread (Carpes et al., 2007). This is due to the variation of the floral sources origin of analyzed pollen(Campos et al., 2010). Some variation can also be due to the different quantification methods that have been used in the different studies.

Polyphenols are part of the chemical composition found in beebread that varies according to the year, botanical origin and collection place (Markiewicz- Zukowska et al., 201;Durán et al., 2014).

Several authors tested different solvents for the preparation of the extracts, such as methanol, ethanol, hexane or water, in order to evaluate their 
Tab. 1. Content of bioactive compounds in beebread using different solvents (Stanciu et al., 2007)

\begin{tabular}{lccc}
\hline \multicolumn{1}{c}{ Solvent } & $\begin{array}{c}\text { Total phenolics } \\
\text { (mg GAE/gbee-bread) }\end{array}$ & $\begin{array}{c}\text { Total flavonoids } \\
\text { (mg QE/gbee-bread) }\end{array}$ & $\begin{array}{c}\text { Flavanones } \\
\text { (mgNAE/g bee-bread) }\end{array}$ \\
\hline Methanol extracts & 22.72 & 0.696 & 7.86 \\
\hline Water extracts & 15.84 & 0.352 & 3.41 \\
\hline Ethanol extracts & 8.32 & 0.168 & 6.04 \\
\hline Methanol70: water30 & 11.90 & 0.624 & 5.38 \\
\hline Ethanol70:water30 & 9.12 & 0.256 & 3.12 \\
\hline
\end{tabular}

Tab. 2. Antioxidant activity of beebread using different solvents (Stanciu et al., 2007)

\begin{tabular}{lccc}
\hline \multicolumn{1}{c}{ Solvent } & $\begin{array}{c}\text { DPPH } \\
\text { Inhibition }(\%)\end{array}$ & $\begin{array}{c}\text { TEAC } \\
(\boldsymbol{\mu} \text { mol Trolox } / \mathbf{g})\end{array}$ & $\begin{array}{c}\text { FRAP } \\
(\boldsymbol{\mu} \text { mol Trolox / g) }\end{array}$ \\
\hline Methanol extracts & 90.35 & 0.43 & 0.404 \\
\hline Water extracts & 62.30 & 0.23 & 0.343 \\
\hline Ethanol extracts & 55.69 & 0.16 & 0.196 \\
\hline Methanol70:water30 & 70.80 & 0.25 & 0.327 \\
\hline Ethanol70:water30 & 56.80 & 0.14 & 0.254 \\
\hline
\end{tabular}

influence on the concentration of the bioactive compounds and their bioactive proprieties (Table 1 and 2). The data show that this content depends on the methods used for extraction. In the paper of Stanciu et al., (2007), the best extraction efficiency was obtained in methanol.

Using HPLC and GS-MS methodsdifferent biologic active compounds were identified in beebread (Table 3), such as p-coumaric acid, kaempferol, two forms of quercetin, apigenin and isorhamnetin (Baltrušaitytè et al., 2007b; Isidorov et al., 2009). It has been suggested that the pollen of different botanical origin have different antioxidant capacity, which is more related to the specific flavone and phenolic acid profiles than to the total content of flavones (Almaraz-Abarca et al., 2004) for this reason flavonoids may serve as biochemical markers of the particular plant source (Čeksterytèet al., 2016). Apart from the compounds mentioned above, Isidorov et al., (2009) also detected trace of ferulic and caffeic acids, chrysin and naringenin.

Tavdidishvili et al. (2014) analyzed the flavonoids content in Georgian beebread and also identified naringin, rutin and quercetin in amount of $20 \%$ of full content of flavonoids.

Also in 2016, Hryniewicket al., identified in beebread samples lipophilic antioxidants such as $\alpha$-tocopherol and coenzyme Q10 which play essential regulatory and metabolic functions in each cell of living organisms. It is involved in a regeneration of tocopheryl radicals. The biological function of $\alpha$-tocopherol, and coenzyme Q10 is not to be underestimated.

Radical scavenging activity of beebread phenolic extracts was assessed by Baltrušaitytè et al. (2007b). The authors reported that after thermal processing, beebread had comparable inhibition of $\mathrm{ABTS}^{+}$radical cation and higher antioxidant activity in the DPPH reaction system than samples of honey and beebread mixed with honey.

Japanese researchers found that total phenolic content yielded $0.24 \mathrm{mg} / \mathrm{ml}$ in Lithuanian beebread ethanol extract while total phenolic content extracted from beebread with distilled boiling water or with water at $20^{\circ} \mathrm{C}$ was 0.20 and $0.45 \mathrm{mg} / \mathrm{ml}$, respectively (Nagai et al., 2004).

According to numerous authors (Gulcin et al., 2003; Baltrušaitytè et al., 2007b; MarkiewiczZukowska et al., 2013) there is a significant antioxidant activity in beebread anda significant correlation between the biologic activity of this product and its botanical origin.

Many of the present studies showed that the bioactive compounds that can be found in 
Tab. 3. Bioactive compounds of beebread

\begin{tabular}{|c|c|c|}
\hline Compound & Value & References \\
\hline $\mathrm{DPPH}^{*}(\%)$ & $94.0-89.9$ & Baltrusaityte et al., 2006 \\
\hline DPPH (mg TE/g) & 1.14 & Ceksteryte et al., 2016 \\
\hline $\mathrm{ABTS}^{*}+(\%)$ & $73.2-92.2$ & Baltrusaityte et al., 2006 \\
\hline ABTS (mg TE/g) & 4.86 & Baltrusaityte et al., 2006 \\
\hline \multirow{2}{*}{$\begin{array}{l}\text { Total flavonoids, } \\
\text { (mg eq-quercitine/g) }\end{array}$} & $1.9-4.5$ & Zuluga et al., 2015 \\
\hline & 0.14 & Stanciu et al.,2008 \\
\hline Flavonones(mg NAE/g) & 12.99 & Stanciu et al.,2008 \\
\hline \multirow{5}{*}{$\begin{array}{l}\text { Total phenols } \\
\text { (mg eq-gallic acid/g) }\end{array}$} & $2.5-13.7$ & Zuluga et al., 2015 \\
\hline & 13.92 & Stanciu et al.,2008 \\
\hline & $4.9-9.5$ & Stanciu et al.,2012 \\
\hline & $33.4-36.5$ & Markiewicz-Zukowska et al., 2016 \\
\hline & 21.2 & Ceksteryte et al., 2016 \\
\hline \multirow{2}{*}{$\begin{array}{l}\text { FRAP } \\
(\mu \text { moltrolox/g) }\end{array}$} & $35.0-70.1$ & Zuluga et al., 2015 \\
\hline & 52.0 & Stanciu et al.,2008 \\
\hline \multirow{2}{*}{$\begin{array}{l}\text { TEAC } \\
(\mu \text { moltrolox/g) }\end{array}$} & $46.1-76.3$ & Zuluga et al., 2015 \\
\hline & 21.0 & Stanciu et al.,2008 \\
\hline $\mathrm{L}^{-O R A C} \mathrm{FL}_{\mathrm{FL}}(\mu \mathrm{mol} \mathrm{TE} / \mathrm{g})$ & $3.8-11.0$ & Stanciu et al.,2012 \\
\hline $\mathrm{H}-\mathrm{ORAC}_{\mathrm{FL}}(\mu \mathrm{mol} \mathrm{TE} / \mathrm{g})$ & $9.34-13.0$ & Stanciu et al.,2012 \\
\hline ORAC(mg TE/g) & 626.30 & Markiewicz-Zukowska et al., 2016 \\
\hline \multirow{2}{*}{$\begin{array}{l}\text { Total antioxidant capacity } \\
(\mu \mathrm{mol} \mathrm{TE} / \mathrm{g})\end{array}$} & $14.9-22.96$ & Stanciu et al.,2008 \\
\hline & $5.6-11.1$ & Markiewicz-Zukowska et al., 2016 \\
\hline p-cumaric acid (\%) & $0.1-0.4$ & Isidorov et al., 2009 \\
\hline Kaempferol (\%) & $0.08-0.4$ & Isidorov et al., 2009 \\
\hline Tocopherol, (\%) & $0.3-0.5$ & Isidorov et al., 2009 \\
\hline Isorahamnetin, (\%) & $0.4-0.9$ & Isidorov et al., 2009 \\
\hline Chrysin (\%) & Trace & Isidorov et al., 2009 \\
\hline Apigenin, $(\%)$ & Trace & Isidorov et al., 2009 \\
\hline Provitamin A (mg/100g) & $200-875$ & Del Risco, 2004 \\
\hline \multirow{2}{*}{$\begin{array}{l}\text { Vitamin E } 9 \text { Tocopherol) } \\
\text { (mg/100 g) }\end{array}$} & $43.6-103.6$ & Hryniewick et al., 2016 \\
\hline & 170 & Del Risco, 2004 \\
\hline Coenzyme Q10 $(\mu \mathrm{g} / \mathrm{g})$ & $8.7-14.6$ & Hryniewick et al., 2016 \\
\hline Vitamin C (mg/100 g) & $6-2000$ & Del Risco, 2004 \\
\hline
\end{tabular}

beebread include carotenoids (provitamin A) and vitamins C, B, E, K (Del Risco, 2004).

There are various methods available in the assessment of the antioxidant capacity of beebreadsamples. It is recommended to use at least two methods to assess and compare the antioxidant capacity (Sakanaka and Ishihara, 2008). They provide useful data, however, they are not sufficient to estimate a general antioxidant ability of the sample (Filipiak, 2001). These methods differ in terms of assay principles and experimental conditions. Consequently, in different methods, particular antioxidants have varying contributions to total antioxidant potential. The enzymatic and non-enzymatic methods are used to determine the antioxidant capacity. From the non-enzymatic methods, indirect methods (DPPH, ABTS+, FRAP) and direct methods (ORAC method) are used mostly. 
Nevertheless, the wide varieties in pollen species, the recognized link of pollen to geographical origin and the lack of knowledge in some aspects, restrict the generalization of the results (Zuluaga et al., 2014).

Beebread contain enzymatic and non-enzymatic antioxidants: glucose oxidase, catalase, ascorbic acid, flavonoids, also phenolic and other organic acids, producing nutritional and biological effects: antimicrobial, antioxidant, anti-inflammatory (Baltrušaitytė et al., 2007a, Baltrušaitytė et al., 2007b, Čeksterytè, 2002).

Until now, there are only a few studies regarding the effects of beebread in human health. The benefits of beebread on the hepatic function and blood parameters in alcohol abuse patients suffering from chronic hepatitis was demonstrated in the study of Čeksterytè et al., (2012). The results showed that beebread helps to regulate the lipid metabolism and exerts a positive effect on the immune system of patients suffering from chronic arthritis and cardiovascular diseases and type 2 diabetes. The conclusion of this study was that beebread used together with medicaments and Livosan supplement exerted a hepatoprotective effect and improved liver function.

Good results of treatment with pollen and bee bread were gained in geriatrics in the symptoms of early old age as well as in neurasthenic inertia in older people (Komosinska-Vassev et al., 2015).

The detoxifying activity of pollen and bee bread in phenomena such as occupational diseases, heavy metal contamination, industrial gases and dusts, and drugs (antirheumatic and anti-inflammatory preparations and antibiotics) should also be mentioned (Eraslan et al., 2009).

Regarding the biological effects of beebread on animals there is a study of Awad et al., 2013 who used beebread as a growth promoter and natural antioxidant in the Sinaichickens diets.The results were encouragingenhancing growth performance and meat composition.

Future studies arerequired to demonstrate other benefic effects of bee bread on human and also on animal health.

\section{Digestibility of beebread}

The quality of bee pollen, in terms of nutrition, depends mainly on its digestibility and bioavailability, which appears to be closely related to some morphological characteristics of the outer wall of the pollen (Bogdanov, 2011; Cook et al., 2003).

Previous researches suggest that the availability of nutritional and bioactive compounds of beebread is limited and, therefore, its use as food (Cook et al., 2003). In the last years, there have been some doubts on the ability of the human digestive system to break the outer layer who overlying the pollenand to absorb nutrients and bioactive substances that are inside it.

Different simulations in vitro of human digestion suggest that the beepollen is partially digested between 48\% and 59\% (Campos et al.,2010) and anthropological studies found coprolites (dried human excretions) with intact pollens, which has been used by some researchers as evidence of the strength of the outer wall of pollen, even to gastric acid (Rimpler et al., 2003).

This study reflects the need to find alternatives for transforming beepollen for an integral use of this product. Despite the absence of conclusive data, the common view of different researchers is that bee pollen is insufficiently digested and a breaking of this outer wall would improve the digestibility and bioavailability (Campos et al.,2010;Rimpler et al., 2003).

The beebread has a better bioavailability because the outer layer who overlying the pollen is partly destroyed by the natural fermentation process, therefore, the functionally and energetically rich content of pollen can be assimilated and used easier by the human body (Mutsaers et al., 2005).

Experiments regarding in vitro human digestion revealed that pollen is partially digested; specifically between $38.7 \%$ and $85.3 \%$ of protein was digested $/ 100 \mathrm{~g}$ pollen, while the digestibility of beebread instead is until $94.7 \%$ protein digested/100 g bee-bread (Zuluaga et al., 2015).

\section{Antimicrobial and antitumor activity}

Increasing evidence suggests beebread's potential therapeutic benefits, including antioxidant (Leja et al., 2007; Kroyer and Hegedus, 2001; Roldán et al., 2001), and antimicrobial properties (Basim et al., 2006; Carpes et al., 2007; Morais et al., 2011).

Beebread could be useful in prevention of diseases where free radicals are involved due to its antioxidant proprieties (Pascoal et al., 2013, Audisio et al., 2005; Mutsaers et al., 2005; 
Baltrušaityte et al., 2007a). It is considered to be a natural health food which constitutes a potential source of energy and functional components for human consumption (Silva et al., 2006), with a wide range of therapeutic properties.

Abouda et al., (2011) studied the antimicrobial activity of samples of beebread from different regions from Morocco on antibio-ressistent bacterial strains isolated from human pathology including E. coli, Staphylococcus aureus, Bacillus cereus and Pseudomonas aeruginosa. The results revealed that most of strains were inhibited by the dilution $1 / 2$ and $1 / 4$. The results revealed that all the samples showed strong antimicrobial activities on the bacterial strains. Moreover, the Gram positive bacteria were more sensitive to beebread than Gram negativebacteria.

Sobral et al.,(2017) studied the antitumor activity of beebread collected in northeast Portugal against different human tumor cell lines, MCF-7 (breast adenocarcinoma), NCI-H460 (nonsmall cell lung cancer), HeLa (cervical carcinoma) and HepG2 (hepatocellular carcinoma), and also against non-tumor liver cells (porcine liver cells, PLP2). Beebread samples showed moderate antitumor activity; however, none of the beebread samples have shown toxicity for normal cells.

\section{Conclusions}

Beebread is regarded as a valuable special food. Its value is given by the high content in proteins, essential amino acids, fatty acids, carbohydrates, mineral salts and bioactive compounds, which depends on the botanical and geographical origin. Beebread composition and bioactive proprieties have not been studies thoroughly until now and are only few publications which present detailed studies of its chemical composition and proprieties, but worldwide interest increases with highlighting chemical and therapeutic properties of beebread.

\section{References}

1. Abouda Z, Zerdani I, Kalalou I, Faid M, Ahami M T, (2011) The antibacterial activity of Moroccan beebread and beepollen (fresh and dried) against pathogenic bacteria. Res. J. Microbiol. 6: 376-384.

2. Almaraz-Abarca Norma, (2004). Variability of antioxidant activity among honeybee-collected pollen of different botanical origin. Interciencia 29(10): 574-578.

3. Almeida-Muradian LB, Panplona LC, Coimbra S, Barth O M, (2005). Chemical composition and botanical evaluation of dried bee pollen pellets. J. Food Comp. Anal., 18(1):105111.

4. Anđelković B, Jevtić G, Mladenović M, Marković J, Petrović M, Nedić N, (2012). Quality of pollen and honey beebread collected in spring. Journal of Hygienic Engineering and Design 1: 275-277.

5. AranedaDurán X, QuezadaMardones I, Martínez Gutiérrez M, Morales Ulloa D, (2014). Polifenoles totales en pan de abeja (Apis mellifera L.) de colmenas de la Región de La Araucanía. Idesia (Arica)32(1): 107-111.

6. Atkin S, Barrier S, Cui Z, Fletcher P, Mackenzie G, Panel V, Sol V, Zhang X, (2011). UV and visible light screening by individual sporopolleninexines derived from Lycopodium clavatum (club moss) and Ambrosia trifida (giant ragweed). J. Photochem. Photobiol. B Biol 102: 209-217.

7. Awad A L, Beshara M M, Ibrahim A F, Fahim H N, (2013). Effect of using Bee bread as natural supplement on productive and physiological performance of Local Siani chickens.1-during growth period. Egypt poult. 33(2):313330.

8. Baltrušaitytė V, Venskutonis P R, Čeksterytė V, (2007a). Antibacterial activity of honey and beebread of different origin against $\mathrm{S}$. aureus and S. epidermidis. Food Technology and Biotechnology 45(2): 201-208.

9. Baltrušaitytė V, Venskutonis PR, Čeksterytė V, (2007b). Radical scavenging activity of different floral origin honey and beebread phenolic extracts. Food Chemistry 101(2): 502-514.

10. Basim E, Basim H, Özcan M, (2006). Antibacterial activities of Turkish pollen and propolis extracts against plant bacterial pathogens. Journal of Food Engineering 77: 992-996.

11. BeeBread, GOST R 53408-2009,2009/1/1

12. Berene I, Daberte I, Siksan S, (2015). Investigation of beebread and development of its dosage forms. Medicinos, 21(1): 16-22.

13. Bogdanov S, (2011). The Bee Pollen Book. Bern, Switzerland: Bee Product Science, 42.

14. Brodschneider R, Crailsheim K, (2010) Nutrition and health in honey bees. Apidologie41: 278-294.

15. Campos M, Frigerio C, Lopes J, Bogdanov S, (2010). What is the future of Bee-Pollen? J ApiProductApiMedical Sci. 2(4):131-144.

16. Carpes T, Begnini R, Matias de Alencar S, Masson, ML, (2007). Study of preparations of bee pollen extracts, antioxidant and antibacterial activity. Ciência e Agrotecnologia 31: 1818-1825.

17. Čeksterytė V, (2002). Investigation of pollen composition and catalase activity in unifloral summer and polyfloral spring honey. Žemdirbystè. Mokslodarbai, 80(4): 193200.

18. Čeksterytė V, Balžekas J, Baltuškevičius A, Jurgevičius E, (2012). The use of beebread-honey mixture in the treatment of liver diseases in alcohol-dependent patients. Chemical Technology, 60(2): 62-66.

19. Čeksterytė V, Hijme J, (2012). Composition and content of fatty acids in beebread of various fl oral origin, collected 
in Lithuania and prepared for storage in diff erent ways. Chem Technol. 2:57-61.

20. Čeksterytė V,Kurtinaitienė B, Venskutonis PR, Pukalskas A, KazernaviČiūtė R, Balžekas R, (2016). Evaluation of Antioxidant Activity and Flavonoid Composition in Differently Preserved Bee Products. Czech Journal of Food Science 34(2).

21. Čeksterytė V, Navakauskienė R, Treigytė G, Jansen E, Kurtinaitienė B, Dabkevičienė G, Balžekas J, (2016). Fatty acid profiles of monofloral clover beebread and pollen and proteomics of red clover (Trifoliumpratense) pollen. Bioscience, Biotechnology and Biochemistry80(11): 2100-2108.

22. Čeksterytė V, Račys J, Kaškonienè V, Venskutonis PR, (2008). Fatty acid composition in beebread. Biologija. 54(4): 253-257.

23. Cook S, Awmack C, Murray D, Williams I, (2003). Are honey bees' foraging preferences affected by pollen amino acid composition? EcolEntomol. 28(5): 622-627.

24. DeGrandi-Hoffman G, Bruce J, Eckholm, Ming Hua Huang, (2013). A comparison of beebread made by Africanized and European honey bees (Apismellifera) and its effects on hemolymph protein titers. Apidologie 44(1): 52-63.

25. Del Risco C, Pérez A, Álvarez V, Rodríguez G, Leiva V, Puig Y, García R, (2012). Lactic acid bacteria to silage bee pollen, Rev. CENIC CienciasBiológicas 43: 17-21.

26. Dominguez-Valhondo D, Bohoyo GD, Herna'ndez MT, Gonzalez-Gomez D, (2011). Influence of the commercial processing and floral origin on bioactive and nutritional properties of honey bee-collected pollen. International Journal of Food Science \& Technology 46: 2204-2211.

27. Eraslan G, Kanbur M, Silici S, Liman B, Altinordulu Ş, Sarica ZS, (2009). Evaluation of protective effect of bee pollen against propoxur toxicity in rat. Ecotoxicology and Environmental Safety, 72(3):931-937.

28. Filipiak M, (2001). Electrochemical analysis of polyphenolic compounds, analytical sciences, supplement. The Japan Society for Analytical Chemistry 17: 1667-1670.

29. Foote HL, (1957). Possible use of microorganisms in synthetic beebread production. Amer. Bee J. 97:476-478.

30. Fuenmayor C, (2009). Bioprocess application in bee pollen development of a protein nutritional supplement. Universidad Nacional de Colombia, Bogotá, Colombia.

31. Fuenmayor C, Zuluaga C, Diaz C, Quicazán M, Cosio M, Mannino S, (2014). Evaluation of the physicochemical and functional properties of Colombian bee pollen. Rev. MVZ Córdoba 19: 4003-4014.

32. Gulcin I, Buyukokuroglu ME, Oktay M, Kufrevioglu O, (2003). Antioxidant and analgesic activities of turpentine of Pinus nigraArn.subsp. pallsiana(Lamb.) Holmboe. J. Ethnophar. 86: 51-58.

33. Haydak MH, (1958). Pollen - pollen substitutes beebread. Amer. Bee J. 98:145-146.

34. Hryniewicka M, Karpinska A, Kijewska M, Turkowicz MJ, Karpinska J, (2016). LC/MS/MS analysis of $\alpha$ tocopherol and coenzyme Q10 content in lyophilized royal jelly, beebread and drone homogenate. Journal of Mass Spectrometry 51(11): 1023-1029.
35. Human H, Nicolson SW, (2006). Nutritional content of fresh, beecollected and stored pollen of Aloe greatheadii var. davyana (Asphodelaceae). Phytochemistry. 67(14):1486-1492.

36. Isidorov VA, Isidorova AG, Szczepaniak L, Czyżewska U, (2009). Gas chromatographic-mass spectrometric investigation of the chemical composition of beebread. Food Chemistry 115(3): 1056-1063.

37. Kaplan M, Karaoglu Ö, Eroglu N, Silici S, (2016). Fatty Acid and Proximate Composition of Beebread. Food Technology \& Biotechnology54(4).

38. Komosinska-Vassev K, Olczyk P, Kaźmierczak J, Mencner L, Olczyk K, (2015). Bee pollen: chemical composition and therapeutic application. Evidence-Based Complementary and Alternative Medicine.

39. Krell R, (1996). Value-added products from beekeeping, FAO Agric. Serv. 124: 87-113.

40. Kroyer G, HegedusN, (2001). Evaluation of bioactive properties of pollen extracts as functional dietary food supplement. Innovative Food Science \& Emerging Technologies 2(3): 171-174.

41. Leja M, Mareczek A, Wyżgolik G, Klepacz-Baniak J, Czekońska K, (2007). Antioxidative properties of bee pollen in selected plant species. Food Chemistry100(1): 237-240.

42. Markiewicz-Żukowska R, Naliwajko SK, Bartosiuk E, Moskwa J, Isidorov V, Soroczyńska J, Borawska MH, (2013). Chemical composition and antioxidant activity of beebread, and its influence on the glioblastoma cell line (U87MG). Journal of Apicultural Science57(2): 147-157.

43. Morais M, Moreira L, Feás X, Estevinho LM, (2011). Honeybee-collected pollen from five Portuguese Natural Parks: Palynological origin, phenolic content, antioxidant properties and antimicrobial activity. Food and Chemical Toxicology 49: 1096-1101.

44. Mutsaers M, van Blitterswijk H, van't Leven L, Kerkvliet J, van de Waerdt J, (2005). Bee products properties, processing and marketing. Agromisa Foundation. Wageningen 34-35.

45. Nagai T, Nagashima T, Myoda T, Inoue R, (2004). Preparation and functional properties of extracts from beebread. Molecular Nutrition \& Food Research48(3): 226-229.

46. Pascoal A, Rodrigues S, Teixeira A, Feás X, Estevinho LM, (2013). Biological activities of commercial bee pollens: Antimicrobial, antimutagenic, antioxidant and antiinflammatory. Food and Chemical Toxicology 63: 233-239.

47. Rimpler M, Von BienenGesammelteBlütenpollen, (2003). Eigenschaften und Verwendung. Ärztezeitschriftfür Naturheilverfahren 44(3):158-165.

48. Roldán A, van Muiswinkel GCJ, Lasanta C, Palacios V, Caro I, (2011). Influence of pollen addition on mead elaboration: Physicochemical and sensory characteristics. Food Chemistry 126: 574-582.

49. Sakanaka S, Ishiharay, (2008). Comparison of antioxidant properties of persimmon vinegar and some other commercial vinegars in radical-scavenging assays and 
on lipid oxidation in tuna homogenates. Food Chemistry $107(2): 739-744$.

50. Salazar-González C, Díaz-Moreno C, (2016). The nutritional and bioactive aptitude of bee pollen for a solid-state fermentation process. Journal of Apicultural Research 55(2): 161-175.

51. Silva TMS, Camara CA, Lins ACS, Barbosa-Filho JM, Silva EMS, Freitas BM, (2006). Chemical composition and free radical scavening activity of pollen loads from stingless bee MeliponasubnitidaDucke. Journal of Food Composition and Analysis 19 (6-7): 507-511.

52. Sobral F, Calhelha RC, Barros L, Dueñas M, Tomás A, SantosBuelga C, Ferreira IC, (2017). Flavonoid Composition and Antitumor Activity of Beebread Collected in Northeast Portugal. Molecules22(2): 248.

53. Stanciu O, Marghitas L, Dezmirean D, (2007). Examination of antioxidant capacity of beebread extracts by different complementary assays. Bulletin of University of
Agricultural Sciences and Veterinary Medicine ClujNapoca. Animal Science and Biotechnologies 64(1-2).

54. Stanciu OG, Mărghitaș L, Dezmirean D, (2009). Macroand Oligo-Mineral Elements from Honeybee-Collected Pollen and Beebread Harvested from Transylvania (Romania). Bulletin of University of Agricultural Sciences and Veterinary Medicine Cluj-Napoca. Animal Science and Biotechnologies 66.

55. Tavdidishvili D, Khutsidze T, Pkhakadze M, Vanidze, M, Kalandia A, (2014). Flavonoids in Georgian Beebread and Bee Pollen. Journal of Chemistry and Chemical Engineering8(7).

56. Zuluaga CM, Serrato JC, Quicazan M, (2015). Chemical, nutritional and bioactive characterization of Colombian beebread. Chemical Engineering Transactions 43: 175180.

57. Zuluaga CM, Serrato JCB, Quicazán MC, (2014). Valorization alternatives of Colombian bee-pollen for its use as food resource - a structured review. Vitae 21(3):237-247. 